\title{
CONTENT OF NITRATES V AND III AND HEAVY METALS IN SELECTED BRASSICA VEGETABLES DEPENDING ON STORAGE
}

\author{
Anna Czech, Elżbieta Rusinek \\ Department of Biochemistry and Toxicology \\ Agricultural University in Lublin
}

\begin{abstract}
The study has been performed to analyze the content of nitrates V and III as well as lead and cadmium in Brassica vegetables, both fresh and after 5-month storage in a cool storeroom. The experimental material consisted of Chinese cabbage, red and white cabbage, savoy cabbage and Brussels sprouts. The content of nitrates in the plant material was determined with the spectrophotometric method based on Griess reaction, whereas concentrations of heavy metals were assayed with the AAS method after dry mineralization.

The 5-month storage period was found to decrease (by $c a$ 65 $55 \%$ ) the content of nitrates $\mathrm{V}$ in savoy cabbage and Brussels sprouts. In turn, a $c a$ 2-fold increase in the concentration of these compounds was determined in Chinese cabbage, and a similar tendency was observed in white cabbage. Chinese cabbage turned out to be the richest in the analyzed, undesirable elements and compounds, e.g. after storage it was characterized by an exceeded permissible level of nitrates $\mathrm{V}\left(750 \mathrm{mg} \mathrm{kg}^{-1}\right.$ f.w.) and by the biggest, $c a$ 10 -fold, increase in concentrations of lead and cadmium. Besides, storage was observed to cause a significant increase in the content of nitrates III in the analyzed vegetables, except red cabbage, in which their content was shown to decrease by about $40 \%$.

Concentrations of nitrates III and $\mathrm{V}, \mathrm{Pb}^{2+}$ and $\mathrm{Cd}^{2+}$ in tissues of the cabbage plants should be monitored regularly in order to prevent their excessive accumulation in the food chain of man.
\end{abstract}

Key words: Brassica vegetables, storage, nitrates V, nitrates III, heavy metals.

dr hab. prof. nadzw. Anna Czech, Department of Biochemistry and Toxicology, University of Life Science in Lublin, Poland, phone: 081 4456746, e-mail: annaczech@poczta.fm 


\title{
ZAWARTOŚĆ AZOTANÓW V I III ORAZ METALI CIĘŻKICH W WYBRANYCH
} WARZYWACH KAPUSTNYCH W ZALEŻNOŚCI OD CZASU PRZECHOWYWANIA

\begin{abstract}
Abstrakt
Celem badań było przeanalizowanie zawartości azotanów V i III oraz ołowiu i kadmu w świeżych warzywach kapustnych i po ich 5-miesięcznym przechowywaniu w chłodnych magazynach. Materiał badawczy stanowiły: kapusta pekińska, kapusta głowiasta czerwona i biała, kapusta włoska oraz kapusta brukselska. W materiale roślinnym zawartość azotanów oznaczono metodą spektrometryczną, opartą na reakcji Griessa, natomiast metale ciężkie - metodą AAS po mineralizacji suchej.

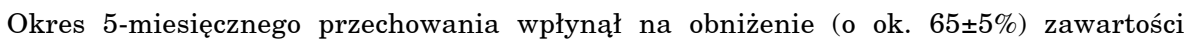
azotanów V w główkach kapusty włoskiej i brukselskiej, natomiast ok. 2-krotny wzrost koncentracji tych związków odnotowano w kapuście pekińskiej, podobną tendencję zaobserwowano w przypadku kapusty białej. Kapusta pekińska okazała się warzywem najbardziej skażonym substancjami niepożądanymi, po przechowywaniu bowiem odnotowano przekroczenie (750 $\mathrm{mg} \mathrm{kg}^{-1}$ ś.m.) zawartości azotanów V oraz największy, ok. 10-krotny wzrost zawartości ołowiu i kadmu. Przechowywanie spowodowało istotny wzrost zawartości azotanów III w analizowanych warzywach z wyjątkiem kapusty głowiastej czerwonej, w której nastąpił ok. 40\% spadek koncentracji omawianych związków.

W celu zapobiegania nadmiernemu gromadzeniu się tych związków w łańcuchu pokarmowym człowieka, niezbędne jest regularne monitorowanie azotanów V i III oraz $\mathrm{Pb}^{2+}$ i $\mathrm{Cd}^{2+} \mathrm{w}$ tkankach badanych roślin.
\end{abstract}

Słowa kluczowe: warzywa kapustne, przechowywanie, azotany V, azotany III, metale ciężkie.

\section{INTRODUCTION}

Vegetables are an essential component of human diet. They are a rich source of vitamins, minerals and dietary fibre. Unfortunately, they are also among the major sources of nitrates in foodstuffs (50-80\%). Presence of some quantities of nitrates $\mathrm{V}$ and III in plants is a natural consequence of the nitrogen cycle in nature. Nevertheless, errors made during cultivation and storage of plant material coupled by limited oxygen access may trigger undesirable biochemical transformations, which in turn can modify the concentrations of nitrates. Although nitrates $\mathrm{V}$ do not pose any serious health problem, a product of their microbiological reduction, i.e. nitrates III, are highly toxic. In addition, genetic traits of vegetables that depend on a species or variety also influence accumulation of these compounds (RUTKOWSKA 1996, Wojciechowska 2005, Rusinek, CZech 2007).

Another serious problem is food contamination with heavy metals. Lead and cadmium may enter the human body through the alimentary and respiratory systems and are capable of accumulating in human tissues. The major source of $\mathrm{Pb}$ and $\mathrm{Cd}$ are environmental pollutants, i.e. wastewater, solid 
waste, dust emitted to the atmosphere, chemical fertilizers, and pesticides (Lo Coco et al. 2000, Yusuf et al. 2003, КHAiRiah et al. 2004, RusineK, Czech 2007). The excess of these metals in food is implicated to raise the incidence of many diseases of the cardiovascular, respiratory and nervous systems. These metals are also involved in carcinogensis and mutagenesis (Steenland, Boffetta 2000, Radwan, Salama 2006).

Owing to the great popularity and high intake of Brassica vegetables in Poland, as well as to increasing environmental pollution, it seems highly advisable to monitor these crops in terms of concentrations of undesirable substances they may contain. The present study has been performed to analyze the content of nitrates V and III as well as lead and cadmium in Brassica vegetables, fresh and stored for 5 months in cool storerooms.

\section{MATERIAL AND METHODS}

The experimental material comprised fresh and stored Brassica vegetables, including: Chinese cabbage (Brassica pekinensis Rupr.), red cabbage (Brassica oleracea var. capitata L. f. rubra), white cabbage (Brassica oleracea var. capitata L. f. alba), savoy cabbage (Brassica oleracea L. var. sabauda), and Brussels sprouts (Brassica oleracea L. var. gemmifera). The vegetables originating from local producers were purchased in a hypermarket in Lublin (in October 2009). Some of the vegetables were stored for 5 months in cool storehouses, at the optimal temperature $\left(0^{\circ} \mathrm{C}\right)$ and air humidity (95-98\%). Control measurements of the temperature and air humidity were carried out several times.

For each Brassica species, 6 samples were collected in each analytical period in order to determine levels of the undesirable components (nitrates $\mathrm{V}$ and III, lead and cadmium). The determinations were carried out in three replications. In total, 60 samples of Brassica vegetables were assayed.

Prior to chemical analyses, the vegetables underwent the necessary preparations (washing, fragmentation). The prepared plant material was divided into samples: $10 \mathrm{~g}$ of vegetables for analyses of nitrates $\mathrm{V}$ and III, and $5 \mathrm{~g}$ of vegetables for assays of heavy metals.

The content of nitrates $\mathrm{V}$ and III was determined with the spectrophotometric method (acc. to the Polish Standard PN-A-75112), based on Griess reaction. The determination consisted in diazotization of sodium nitrate III with sulfanilamide (Griess reagent I) and mixing with N-1-naphtylethylenediamine (Griess reagent II). The product of this reaction was two-phase, red-violet dye, whose color intensity was measured spectrophotometrically. Nitrates $\mathrm{V}$ were determined through direct reduction with cadmium to nitrates III. 
For determination of lead and cadmium, the samples were pre-dried a drier at $60^{\circ} \mathrm{C}$ for $24 \mathrm{~h}$, and then dried at $105^{\circ} \mathrm{C}$ for another $24 \mathrm{~h}$. Afterwards, the samples were weighed, mineralized in a muffle furnace at $450^{\circ} \mathrm{C}$ and solubilized in $6 \mathrm{~N}$ of spectrally pure hydrochloric acid. The mineralizate was determined for the content of heavy metals with the AAS method after dry mineralization (acc. to the Polish Standard PN-EN 14082), using a UNICAM 939 spectrometer. Lead content was assayed at $\lambda=217.0 \mathrm{~nm}$, whereas cadmium content - at $\lambda=228.8 \mathrm{~nm}$. The analytical range for $\mathrm{Pb}^{2+}$ and $\mathrm{Cd}^{2+}$

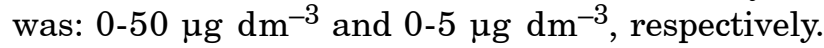

The results were subjected to statistical analysis using Statistica ver. 5 software. The significance of differences between mean values was determined with the one-way analysis of variance test ANOVA.

\section{RESULTS AND DISCUSSION}

The 5-month storage period depressed (by ca $65 \pm 5 \%$ ) the content of nitrates $\mathrm{V}$ in heads of savoy cabbage and Brussels sprouts (Table 1). In contrast, about a 2-fold increase in the concentration of these compounds was determined in Chinese cabbage and a similar tendency was observed in the case of white cabbage. Slightly different dependencies were noted while analyzing the impact of the 5-month storage on the content of nitrates III. The storage was observed to cause a significant increase in nitrates III in the analyzed vegetables, except for red cabbage, in which the concentration of these compounds decreased by about $40 \%(p=0.05)$ - Table 1 . In turn, the biggest increase, by about 5 -fold, in the concentration of nitrates III was determined in white cabbage, whereas the smallest one occurred in Brussels sprouts (ca 2-fold).

The binding EU regulations (Regulation...2006) limit the level of nitrates $\mathrm{V}$ only in vegetables, i.e. in lettuce and spinach. According to the previous Regulation of the Minister of Health (2003), the permissible level of these compounds in Brassica vegetables is $750 \mathrm{mg} \mathrm{kg}^{-1} \mathrm{f} . \mathrm{w}$.

The content of nitrates $\mathrm{V}$ in both fresh and stored vegetables was far below the level of $750 \mathrm{mg} \mathrm{kg}^{-1} \mathrm{f}$.m., except in Chinese cabbage. The pretreatment of vegetable samples may have lowered the content of nitrate compounds, which are easily water soluble (Mondy, Munshi 1990). The stored Chinese cabbage was characterized by a high content of nitrates $\mathrm{V}$, reaching 953.7 f.w. This might have resulted either from the excessive fertilization or from neglecting the pre-harvest interval.

LISIEWSKA and KMIECIK (1991) report that the accumulation of nitrate compounds is affected by light. Diminishing the light intensity or exposure time may increase the content of nitrates $\mathrm{V}$ in vegetables, because a deficient content of carbohydrates produced under insufficient light might be the fac- 


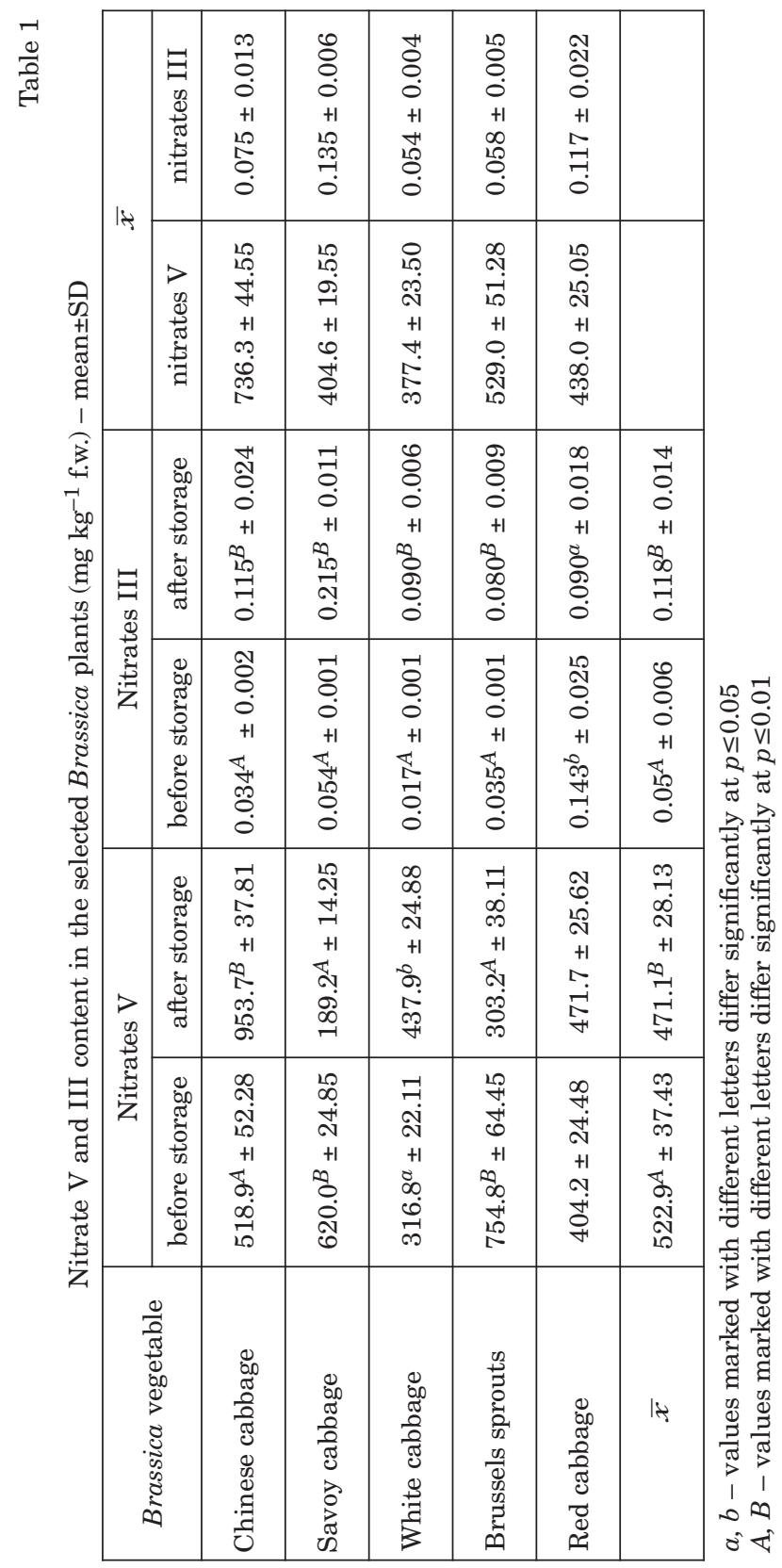


tor diminishing the reduction rate of these compounds. This factor might have caused an increased content of nitrates V and III in the vegetables analyzed in this study (Table 1).

Among the investigated Brassica vegetables, Chinese cabbage had the highest concentration of nitrates V (Figure 1). In contrast, the lowest concentration of $\mathrm{NO}_{3}^{-}$ions was noted in white, savoy and red cabbage, with the value being about $45 \pm 5 \%$ lower than in Chinese cabbage $(p=0.05)$. In

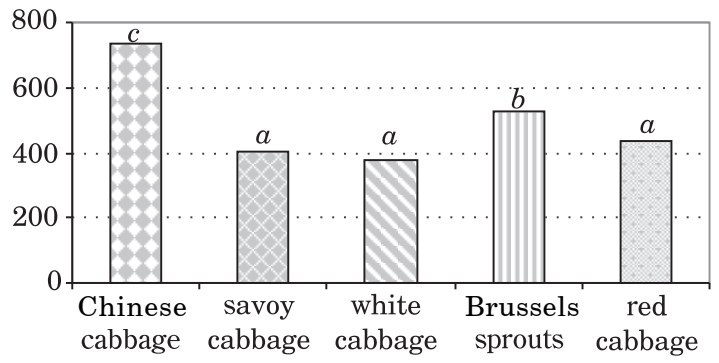

$a, b, c$ - values marked with different letters differ significantly at $p \leq 0.05$

Fig. 1. The mean nitrates $\mathrm{V}$ content in the selected Brassica vegetables ( $\mathrm{mg} \mathrm{kg}^{-1}$ f.w.)

respect of nitrates III, their highest concentration was noted in savoy cabbage, higher than in white cabbage, Chinese cabbage or Brussels sprouts (Figure 2). The values were statistically significant and the differences reached about $50 \%$. Red cabbage was characterized by a significantly lower (by 13\%) content of nitrates III than savoys cabbage, and lower (by 50\%) content of these compounds than in the other analyzed vegetables (Figure 2).

The content of nitrates $\mathrm{V}$ determined in this study was seven-fold lower than the value reported by MuRAwA et al. (2008). Those authors determined the content of nitrates $\mathrm{V}$ in white cabbage at the level of $2642.7 \mathrm{mg} \mathrm{kg}-1$ f.m. In turn, the concentration of nitrates III reported by these authors equalled $0.13 \mathrm{mg} \mathrm{kg}^{-1} \mathrm{f}$.w., which exceeded by about 2.4-fold the values presented in Table 1 . The research by LISIEWSKA and KMIECIK (1991) indicates that the content of nitrates $\mathrm{V}$ in savoy and red cabbage were higher by70\% and $20 \%$, respectively, than in the raw material analyzed in the present research. With respect to white cabbage, the results were comparable, whereas Brussels sprouts were characterized by a lower concentration of $\mathrm{NO}_{2}^{-}$ ions when compared to the values reported in our study. This might have been due to the stage of plant vegetation, for example, because the highest concentration of these compounds is observed in the early developmental stages, when the level of carbohydrates, the major source of energy to their reduction processes, is still low. According to AMR (2000) and MCKNIGHT et al. (1999), vegetables grown in heated greenhouses are characterized by a higher content of nitrates than cultivated on a field or in a tunnel, owing to lesser light intensity and higher nitrogen mineralization. 


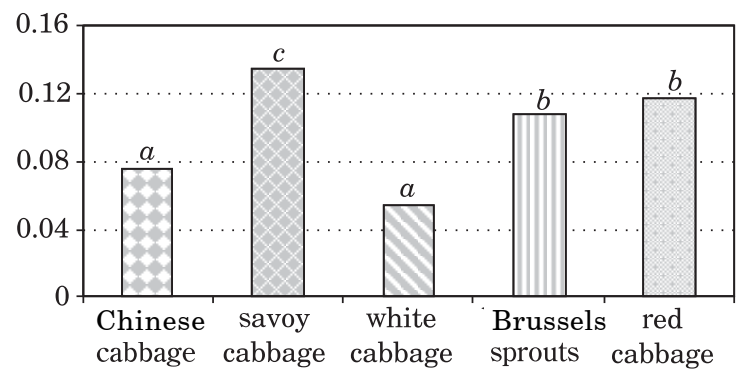

$a, b, c$ - values marked with different letters differ significantly at $p \leq 0.05$

Fig. 2. The mean nitrates III content in the selected Brassica vegetables (mg $\mathrm{kg}^{-1}$ f.w.)

Apart from nitrogen compounds, another group of xenobiotics likely to occur in plants are heavy metals, e.g. lead or cadmium. The uptake of heavy metals by plants is affected mostly by the grain size distribution of soil, which determines its absorption, and by the content of organic matter. For example, cadmium is very mobile in acid soils. The sources of cadmium are combustion of solid and liquid fuels, intensive fertilization with phosphatebased fertilizers, application of calcium and magnesium fertilizers, agricultural application of wastewater sludge, etc. The presence of lead is associated with the composition of soil, but unlike cadmium, lead is easily absorbed by plants from soils poor in organic matter, especially at low $\mathrm{pH}$ (ScotT et al. 1996, Voutsa et al. 1996, ZANIEWICZ-BAJKOWSKA 2002). When comparing the concentration of the two heavy metals $\left(\mathrm{Pb}^{2+}\right.$ and $\left.\mathrm{Cd}^{2+}\right)$ in the investigated Brassica vegetables, the highest levels were determined in Chinese cabbage (Figures 3,4). In savoy, white and red cabbage, the concentrations of lead and cadmium were on a similar level and reached $0.031 \pm 0.003 \mathrm{mg} \mathrm{Pb} \mathrm{kg}^{-1}$

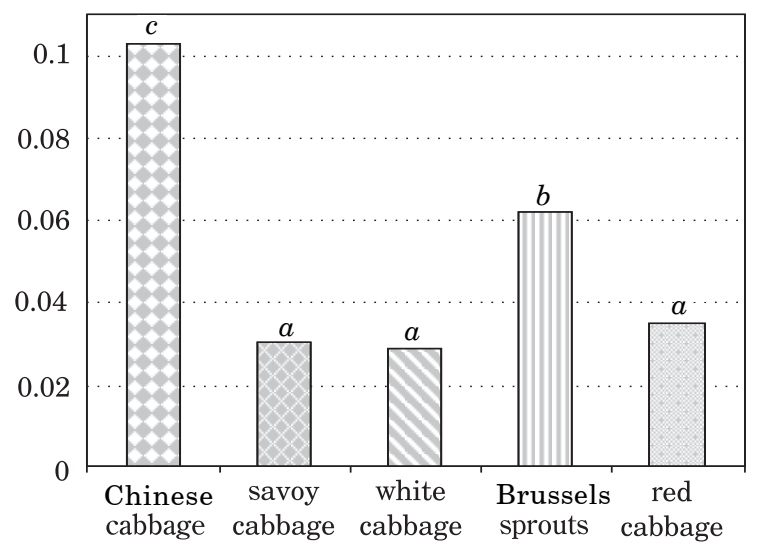

$a, b, c$ - values marked with different letters differ significantly at $p \leq 0.05$

Fig. 3. The mean lead content in the selected Brassica vegetables ( $\mathrm{mg} \mathrm{kg}^{-1}$ f.w.) 


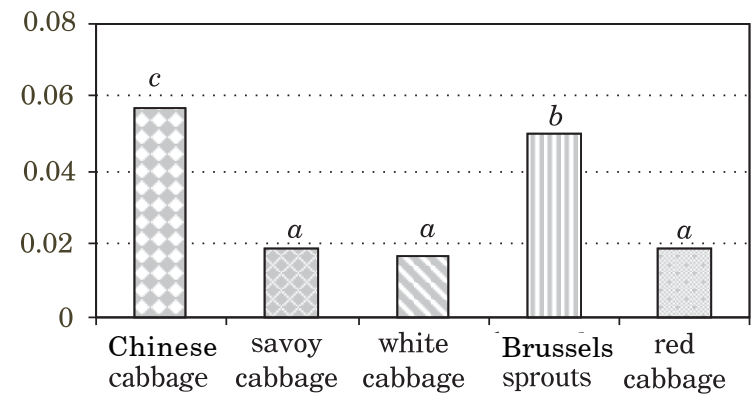

$a, b, c$ - values marked with different letters differ significantly at $p \leq 0.05$

Fig. 4. The mean cadmium content in the selected Brassica vegetables ( $\mathrm{mg} \mathrm{kg}^{-1}$ f.w.)

f.w. and $0.018 \pm 0.002 \mathrm{mg} \mathrm{Cd} \mathrm{kg}{ }^{-1}$ f.w. Noteworthy is the fact that the permissible levels of lead and cadmium, i.e. $0.3 \mathrm{mg} \mathrm{Pb} \mathrm{kg}^{-1}$ and $0.05 \mathrm{mg} \mathrm{Cd}$ $\mathrm{kg}^{-1}$ (Regulation...2006) were not exceeded in any of the Brassica species examined. Higher concentrations of heavy metals in Chinese cabbage than in collards were determined by BAHEMUKA and MuBofu (1999). According to those authors, this was due to the differences in the morpho-physiological characteristics of vegetables, which was confirmed by SINGH and KUMAR (2006). In turn, as claimed by TAHVONEN and KUMULAINEN (1995), the accumulation of heavy metals depends on the part of a plant (roots $>$ leaves $>$ fruit $>$ seeds), as well as the species or variety of plants cultivated under the same conditions. Wong et al. (1996) underlined the fact that Chinese cabbage belongs to vegetables characterized by higher accumulation of lead than other heavy metals, including cadmium, copper, zinc or nickel. This has been confirmed in the reported study, where the analyzed samples of Chinese cabbage had a higher concentration of lead than cadmium (Tables 2 and 3).

The availability of heavy metals is also greatly affected by environmental pollution. In a study by GONTARZ and DMOWSKI (2000), cabbage samples were characterized by the lead content of $0.45 \mathrm{mg} \mathrm{kg}^{-1} \mathrm{f}$.w. Such a high concentration of lead, exceeding the permissible level of contamination, might have resulted from the fact that these vegetables were cultivated in the vicinity of metal smelting plants, i.e. in an area with increased environmental pollution. According to the Regulation of the Minister of Health (2002), the content of lead in soil in industrial areas should not exceed $600 \mathrm{mg} \mathrm{kg}^{-1}$. However, the content of lead in soils in the industrial areas, although below the stipulated permissible levels, is twice as high as in unpolluted regions, including the region of Lubelszczyzna.

As mentioned earlier, the uptake of elements is linked directly with their solubility, which in turn is affected by the following properties of soil: $\mathrm{pH}$, content of organic matter, texture and redox potential. Hence, of outmost significance is the application of appropriate agricultural practices, especially rational organic and mineral fertilization. BEDNAREK et al. (2007) de- 
ล)

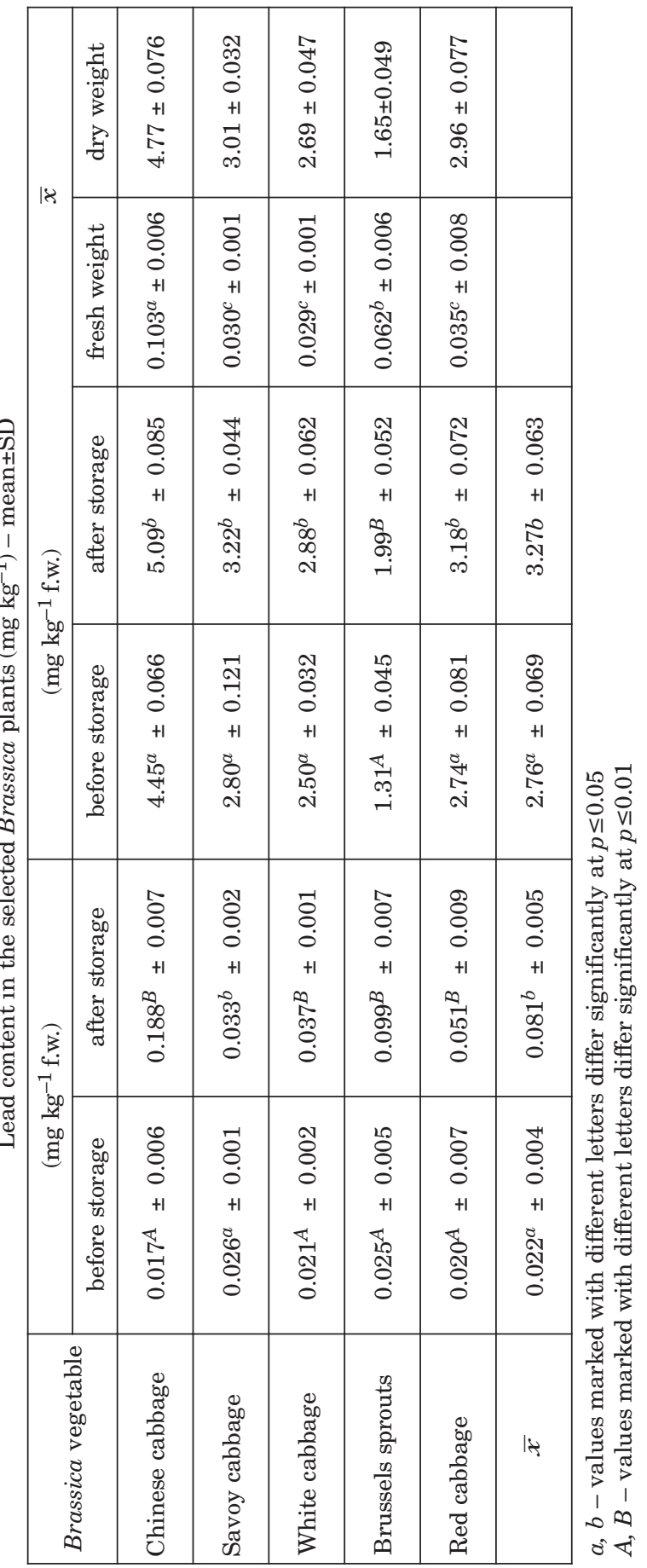


ח

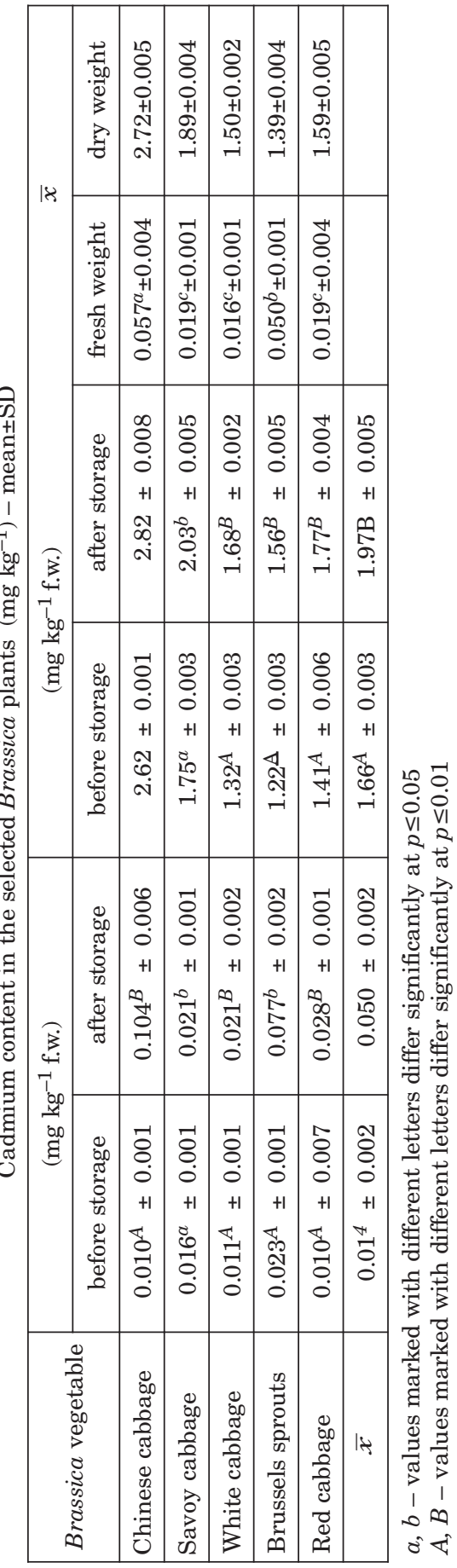


termined the content of cadmium in white cabbage to reach 0.006 $-0.028 \mathrm{mg} \mathrm{kg}^{-1}$, similar to our results. The latter authors also observed a significant correlation between the accumulation of this element in Brassi$c a$ vegetables and its presence in soil (correlation coefficient 0.662 ). The low content of cadmium in the analyzed vegetables may indicate a low pollution level of the environment where they were cultivated, which is undoubtedly typical of the region of Lubelszczyzna, and good agricultural practice (fertilization in particular). It is a very positive finding, showing that producers adhere to the guidelines of the rational cultivation of vegetables sold on the market.

The analyzed Brassica vegetables were observed to be characterized by diversified tendencies for lead and cadmium accumulation in storage organs, as affected by the process of storage. After the 5-month storage period, the highest, about 10-fold, increase (per fresh weight) in the content of both lead and cadmium was noted in Chinese cabbage, whereas the smallest increase (by about 25\%) appeared in savoy cabbage (Tables 2,3 ). The content of these elements in the other analyzed Brassica vegetables was also significantly higher, reaching $80 \pm 15 \%$ in white cabbage. In Brussels sprouts, it was $3.5 \pm 0.5$-fold higher after the storage, and in red cabbage it rose by 2.5 \pm 0.5 -fold. Such a high increase in $\mathrm{Pb}^{2+}$ and $\mathrm{Cd}^{2+}$ in the analyzed vegetables after the five-month storage was likely to be due to high water loss, which reached about $14 \%$ in Chinese cabbage. In the other vegetables, the water loss equalled to $10 \%$ in Brussels sprouts, $4.5 \%$ in red cabbage, and $1 \pm 0.5 \%$ in white and savoy cabbage.

\section{CONCLUSIONS}

1. The 5-month period of storage caused a decrease (by ca $65 \pm 5 \%$ ) in the content of nitrates $\mathrm{V}$ in savoy cabbage heads and in Brussels sprouts. In contrast, a 2 -fold increase in the concentration of these compounds was noted in Chinese cabbage, and a similar tendency was observed in white cabbage.

2. Chinese cabbage turned out to be the richest in the undesirable substances and characterized by an exceeded permissible level of nitrates $\mathrm{V}$ (750 $\mathrm{mg} \mathrm{kg}^{-1}$ f.w.) as well as the highest, ca 10-fold, increase in the content of lead and cadmium after storage.

3. Storage caused a significant increase in the concentration of nitrates III in all the analyzed vegetables except red cabbage, in which the level of these compounds decreased by $c a 40 \%$.

4. In order to prevent excessive accumulation of nitrates $\mathrm{V}$ and III, $\mathrm{Pb}^{2+}$ and $\mathrm{Cd}^{2+}$ in the food chain of man, it seems necessary to monitor regularly their levels in tissues of edible plants. 


\section{REFERENCES}

Aмr. A. 2000. Nitrate and nitrite content of some vegetables grown in central Jordan Valley. Dirasat. Agricultural Sci., 27(3): 410-419.

Bahemuka T.E., Mubofu E.B. 1999. Heavy metals in edible green vegetables grown along the sites of the Sinza and Msimbazi rivers in Dar es Salaam, Tanzania. Food Chem., 66(1): 63-66.

Bednarek W., Tkaczyk P., Dresler S. 2007. Content of heavy metals as a criterion for cabbage quality assessment. Acta Agrophys., 10(1): 7-18. (in Polish)

Commission Regulation (EC) No 1881/2006 of 19 December 2006 setting maximum levels for certain contaminants in foodstuffs. (in Polish)

Gontarz B., Dmowski Z. 2000. Contens of heavy metals in soil and vegetables from gardens near the Hutmen metal smelting plant in Wroclaw. Zesz. Probl. Post. Nauk Rol., 471: 913-919. (in Polish)

Khairiah J., Zalifah M.K., Yin Y.H., Aminha A. 2004. The uptake of heavy metals by fruit type vegetable grown in selected agricultural areas. Pak J. Biol. Sci., 7(8): 1438-1442.

Lisiewska Z., Kмiecik W. 1991. Nitrates and nitrites in vegetables. Part I. Post. Nauk Rol., 91(3): 11-24. (in Polish)

Lo Coco F., Monotti P., Noeelli V., Ceccon L., Adami G., Micali G. 2000. Determination of cadmium and lead in vegetables by stripping chronopotentiometry. Food Addit. Contam., 21(5): 441-446.

McKnight G.M., Duncan C.W., Leifert C., Golden M.H. 1999. Dietary nitrate in man: friend or foe?. Br. J. Nutr., 81(5): 349-358.

Mondy I., Munshi B. 1990. Effect of nitrogen fertilization on glycoalkaloid and nitrate content of potato. J. Agric. Food Chem., 38(2): 565-567.

Murawa D., Banaszkiewicz T., Majewska E., BŁaszczuk B., Sulima J. 2008. Nitrate and nitrite content in selected vegetables and potatoes commercially available in Olsztyn in 2003-2004. Bromat. Chem. Toksykol., 41(1): 67-71. (in Polish)

PN-A-75112. 1992. Fruits, vegetables and derived products. Determination of nitrites and nitrates content. (in Polish)

PN-EN 14082. 2004. Foodstuffs - Determination of trace elements - Determination of lead, cadmium, zinc, cooper, iron and chromium by atomic absorption spectrometry (AAS) after dry ashing. (in Polish)

Radwan M.A., SAlama A.K. 2006. Market basket survey for some heavy metals in Egyptian fruits and vegetables. Food Chem Toxicol., 44(8): 1273-1278.

Regulation of the Ministry for Environment of 9 September 2002 on soil and arable land quality standards. Journal of Laws no 165, item 1359. (in Polish)

Regulation of the Minister of Health of 13 January 2003 on the maximum levels of chemical and biological contaminants that may be present in food, food ingredients, allowed additional substances, substances that help in the processing or on food. (in Polish)

RusineK E., CZECH A. 2007. Nitrate (V), nitrate (III) and heavy metal content in selected root vegetables depending on the shelf life (Part I). Bromat. Chem. Toksykol., 40(1): 15-21. (in Polish)

Rutkowska G. 1996. More about nitrates. Chłodnictwo, 31(12): 38-40. (in Polish)

Scott D., Keoghan J.M., Allen B.E. 1996. Native and low input grasses - a New Zealand high country perspective. New Zealand Agric. J. Res., 39(4): 499-512.

Singh S., Kumar M. 2006. Heavy metal load of soil, water and vegetables in peri-urban Delhi. Environ. Monitor. Assess., 120(1-3): 79-91.

Steenland K., Boffetta P. 2000. Lead and cancer in humans: where are we now? Am. J. Ind. Med., 38(3): 295-299. 
Tahvonen R., Kumulainen J. 1995. Lead and cadmium in some berries and vegetables on the Finnish market in 1991-1993. Food Addit. Contam., 12(2): 263-279.

Voutsa D., Grimanis A., Samara C. 1996. Trace elements in vegetables grown in industrial areas in relation to soil and air particulate matter. Environ. Pollut., 94(3): 325-335.

Wojciechowska R. 2005. Accumulation of nitrates and quality of horticultural products. Wyd. Coperite, Kraków, 21-27. (in Polish)

Wong J.W., Li G.X., Wong M.H. 1996. The growth of Brassica chinensis in heavy metal contaminated sludge compost from Hong Kong. Biores. Technol., 58(3): 309-313.

Yustuf A.A., Arowolo T.A., BamgBose O. 2003. Cadmium, copper and nickel levels in vegetables from industrial and residential areas of Lagos City, Nigeria. Food Chem. Toxicol., 41(3): 375-378.

Zaniewicz-Bajkowska A. 2002. Organic fertilization and liming of the soil and the content of cadmium in vegetables. Part 1: Direct influence. Rocz. Nauk Rol. Ser. A, 116(1): 51-62. (in Polish) 
